\title{
Origins and genetic diversity of the ragweed beetles, Ophraella communa (Coleoptera: Chrysomelidae), that were introduced into Italy and Japan based on an analysis of mitochondrial DNA sequence data
}

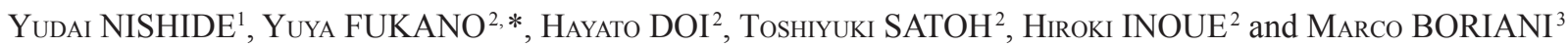 \\ ${ }^{1}$ Locust Research Laboratory, National Institute of Agro-biological Sciences at Ohwashi, 1-2 Ohwashi, Tsukuba, Ibaraki 305-8634, \\ Japan; e-mail: nishiyu0@yahoo.co.jp \\ ${ }^{2}$ Graduate School of Agriculture, Tokyo University of Agriculture and Technology, 3-8-1 Harumi-cho, Fuchu-shi, Tokyo 183-8538, \\ Japan; e-mails: ragweed.beetle@gmail.com; sss_stareyes@yahoo.co.jp; robo_q0j0p@yahoo.co.jp; tsatoh@cc.tuat.ac.jp \\ ${ }^{3}$ Regione Lombardia, Laboratorio fitopatologico, Servizio fitosanitario regionale, Viale Raimondi 54, I-22040 Vertemate con \\ Minoprio (Como), Italy; e-mail: marco_boriani@regione.lombardia.it
}

Key words. Coleoptera, Chrysomelidae, Ophraella communa, invasive species, biological control, Ambrosia artemisiifolia

\begin{abstract}
Ophraella communa (Coleoptera: Chrysomelidae) is an oligophagous herbivorous beetle that feeds on Ambrosia artemisiifolia. It is native to North America, but was accidentally introduced into Japan in 1995 and Europe in 2013. We analyzed partial DNA sequences of the mitochondrial cytochrome oxidase II gene for $O$. communa collected from 29 locations in the United States, Japan and Italy. Overall, the results of our analyses indicate that the introduced Japanese populations have lower genetic variation than the native populations. The sequences for the Italian specimens did not share haplotypes with Japanese specimens. These results indicate that the introduced Japanese populations originated from a single introduction, and that the Italian and Japanese populations have different origins.
\end{abstract}

\section{INTRODUCTION}

Inferring the introduction history from genetic markers is important in elucidating the patterns of colonization and expansion of introduced species and biocontrol agents (Estoup \& Guillemaud, 2010). In some cases, the introduced populations have experienced bottlenecks and founding events. Consequently, they have a reduced genetic variation in their introduced ranges (Hufbauer et al., 2004; Sax et al., 2005). In contrast, if the introduced populations are derived from multiple native populations, then the genetic diversity can be higher than that of native populations (Allendorf \& Lundquist, 2003; Kolbe et al., 2004; Sakai et al., 2001). High genetic diversity caused by multiple introductions presumably facilitates the adaptation of the introduced species to the exotic environment because the level of genetic variation strongly influences the degree and speed of evolutionary change (Barrett \& Schluter, 2008). The resulting evolutionary change in the introduced species could amplify its effect on native ecosystems (Lavergne \& Molofsky, 2007).

Ragweed leaf beetle, Ophraella communa LeSage, is an oligophagous species whose preferred host is ragweed, Ambrosia artemisiifolia L., on which it prefers to feed on the leaves. Ambrosia artemisiifolia is native to North America, but was recently (and accidentally) introduced into many countries in eastern Asia (Japan and Taiwan in 1996, Korea in 2000, mainland China in 2001; Shiyake \& Moriya, 2005) and Europe (Boriani et al., 2013; Bosio et al., 2014; Müller-Schärer et al., 2014). In both its native and exotic ranges, $A$. artemisiifolia is a problematic weed (Ding et al., 2006), because of its high fecundity and production of large amounts of highly allergenic pollen (Bassett \& Crompton 1975, 1982). Ophraella communa is known to be an effective biocontrol agent of introduced populations of $A$. artemisiifolia (Cao et al., 2011, Guo et al., 2011; Zhou et al., 2014).

O. slobodkini is a sibling species to O. communa and also feeds on the leaves of ragweed. O. slobodkini occurs in the southern United States (Florida), and these two species have allopatric distributions (Futuyma, 1991) and can be distinguished from one another genetically and morphologically, but the morphological differences are slight (Futuyma, 1991). Because introduced O. communa have not been investigated using genetic markers, it is possible that the sibling species, O. slobodkini has been introduced (cryptically) into Japan and Italy.

The main purpose of this study is to characterize the genetic structure of native $O$. communa populations in North American and introduced populations of $O$. communa and $O$. slobodkini in Japan and Italy, in order to infer the invasion history in the aforementioned introduced ranges, using genetic markers. We analyzed partial mitochondrial cytochrome oxidase II (COII) DNA sequences, rather than the more traditional COI sequences, because a previous study had shown that COI haplotypes of native O. communa showed no regional clustering pattern (Knowles et

\footnotetext{
* Corresponding author.
} 


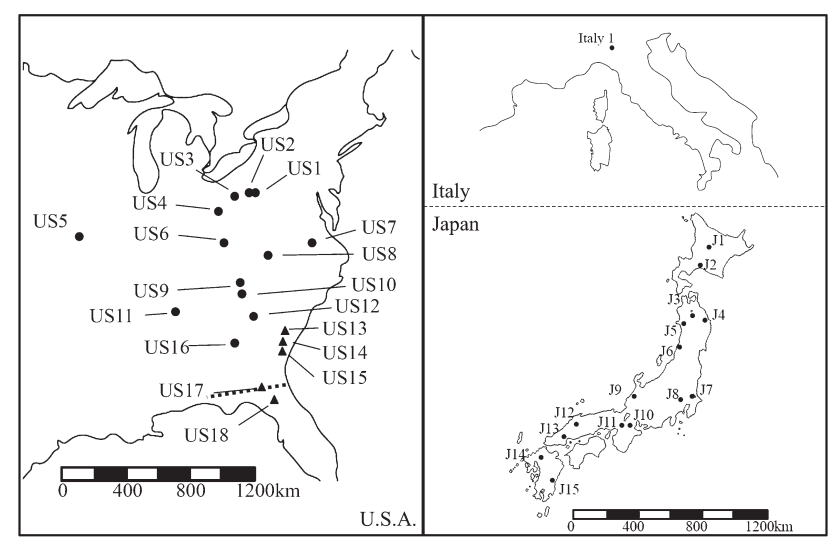

Native range

Introduced range

Fig. 1. Maps showing locations in the native and introduced ranges at which samples were collected. Black circles denote sites where Ophraella communa were sampled. Black triangles denote sites where Ophraella slobodkini were sampled. Dashed line represents the Florida-Georgia border. al., 1999). Specifically, we asked three questions: (1) How much genetic variation exists in Japanese, Italian and native $O$. communa populations? (2) Where are the possible source populations of introduced populations? (3) Has there been a cryptic introduction of the aforementioned regions by Ophraella slobodkini?

\section{MATERIAL AND METHODS}

\section{Collection of samples}

During 2008-2013, a total of 89 individuals of Ophraella were collected from 18 locations in the United States, 15 locations in Japan and the location of a recent introduction in Italy (Table 1, Fig. 1). The individuals were collected by sweeping and hand picking from A. artemisiifolia and A. trifida in the introduced range and from $A$. artemisiifolia in the native range (Fukano \& Doi, 2013). We collected 1-6 individuals per population except for the Italian population $(\mathrm{n}=13)$. These specimens were preserved in ethanol $(99.5 \%)$ until analyzed in the laboratory at Tokyo University of Agriculture and Technology, Japan.

TABLE 1. Localities, year collected and host plants of Ophraella communa (US1-US12, US16, J1-J15 and Italy1) and Ophraella slobodkini (US13-US15, US17 and US18) that were examined using mitochondrial CO II DNA sequencing.

\begin{tabular}{|c|c|c|c|c|c|c|}
\hline No. & Locality & Latitude & Longitude & Year collected & $\mathrm{n}$ & Host plant \\
\hline & Native Area (USA) & & & & & \\
\hline US1 & Trafford, PA & N40.388 & W79.775 & 2010 & 1 & Ambrosia artemisiifolia \\
\hline US2 & Donegal, PA & $\mathrm{N} 40.112$ & W79.398 & 2012 & 2 & Ambrosia artemisiifolia \\
\hline US3 & Valley Grove, WV & N40.091 & W80.536 & 2012 & 2 & Ambrosia artemisiifolia \\
\hline US4 & Williamstown, WV & N39.390 & W81.443 & 2012 & 1 & Ambrosia artemisiifolia \\
\hline US5 & O’Fallon, MO & N38.791 & W90.699 & 2010 & 1 & Ambrosia artemisiifolia \\
\hline US6 & Cabin Creek, WV & N38.197 & W81.507 & 2012 & 1 & Ambrosia artemisiifolia \\
\hline US7 & Innsbrook, VA & N37.624 & W77.598 & 2010 & 4 & Ambrosia artemisiifolia \\
\hline US8 & Blue Redge, VA & $\mathrm{N} 37.410$ & W79.798 & 2008 & 5 & Ambrosia artemisiifolia \\
\hline US9 & Statesville, NC & N35.799 & W80.828 & 2012 & 1 & Ambrosia artemisiifolia \\
\hline US 10 & Robbin Park, NC & N35.454 & W80.885 & 2012 & 1 & Ambrosia artemisiifolia \\
\hline US11 & Acworth, GA & N34.069 & W84.676 & 2012 & 2 & Ambrosia artemisiifolia \\
\hline US12 & Blue Ridge, VA & N34.307 & W81.004 & 2012 & 1 & Ambrosia artemisiifolia \\
\hline US13 & St. George, SC & N33.201 & W80.578 & 2012 & 2 & Ambrosia artemisiifolia \\
\hline US14 & Yamassee, SC & $\mathrm{N} 32.631$ & W80.836 & 2012 & 1 & Ambrosia artemisiifolia \\
\hline US15 & Savannah, GA & N32.072 & W81.199 & 2012 & 3 & Ambrosia artemisiifolia \\
\hline US16 & Forsyth, GA & N33.040 & W83.943 & 2012 & 3 & Ambrosia artemisiifolia \\
\hline US17 & Live Oak, FL & $\mathrm{N} 30.323$ & W82.962 & 2010 & 1 & Ambrosia artemisiifolia \\
\hline \multirow[t]{2}{*}{ US18 } & Millpond, FL & $\mathrm{N} 29.681$ & W82.448 & 2010 & 5 & Ambrosia artemisiifolia \\
\hline & Introduced Area (Japan) & & & & & \\
\hline $\mathrm{J} 1$ & Asahikawa, Hokkaido & N43.769 & E142.330 & 2009 & 1 & Ambrosia artemisiifolia \\
\hline $\mathrm{J} 2$ & Tomakomai, Hokkaido & N42.665 & E141.662 & 2009 & 2 & Ambrosia artemisiifolia \\
\hline $\mathrm{J} 3$ & Hirosaki, Aomori & N40.599 & E140.436 & 2009 & 1 & Ambrosia artemisiifolia \\
\hline $\mathrm{J} 4$ & Hachinohe, Aomori & N40.516 & E141.529 & 2009 & 1 & Ambrosia trifida \\
\hline J5 & Minamiakita, Akita & N39.947 & E140.159 & 2009 & 2 & Ambrosia artemisiifolia \\
\hline J6 & Higashitagawa, Yamagata & N38.633 & E140.012 & 2009 & 3 & Ambrosia artemisiifolia \\
\hline $\mathrm{J} 7$ & Tsukuba, Ibaragi & N36.024 & E140.106 & 2009 & 1 & Ambrosia artemisiifolia \\
\hline J8 & Tachikawa, Tokyo & N35.689 & E139.387 & 2009 & 2 & Ambrosia trifida \\
\hline J9 & Kanazawa, Ishikawa & N36.569 & E136.634 & 2011 & 3 & Ambrosia trifida \\
\hline $\mathrm{J} 10$ & Tsuchiyama, Mie & N34.934 & E136.288 & 2011 & 5 & Ambrosia artemisiifolia \\
\hline J11 & Yawata, Kyoto & N34.887 & E135.692 & 2011 & 2 & Ambrosia trifida \\
\hline $\mathrm{J} 12$ & Izumo, Shimane & N35.335 & E132.886 & 2011 & 2 & Ambrosia trifida \\
\hline $\mathrm{J} 13$ & Yamagichi, Yamaguchi & N34.309 & E131.584 & 2011 & 6 & Ambrosia artemisiifolia \\
\hline $\mathrm{J} 14$ & Kasuya, Fukuoka & N33.623 & E130.495 & 2011 & 5 & Ambrosia trifida \\
\hline \multirow[t]{2}{*}{$\mathrm{J} 15$} & Miyakonojo, Miyazaki & $\mathrm{N} 31.705$ & E131.094 & 2011 & 2 & Ambrosia trifida \\
\hline & Introduced Area (Italy) & & & & & \\
\hline Italy1 & Broni, Lombardia & N45.075 & E9.275 & 2013 & 13 & Ambrosia artemisiifolia \\
\hline
\end{tabular}




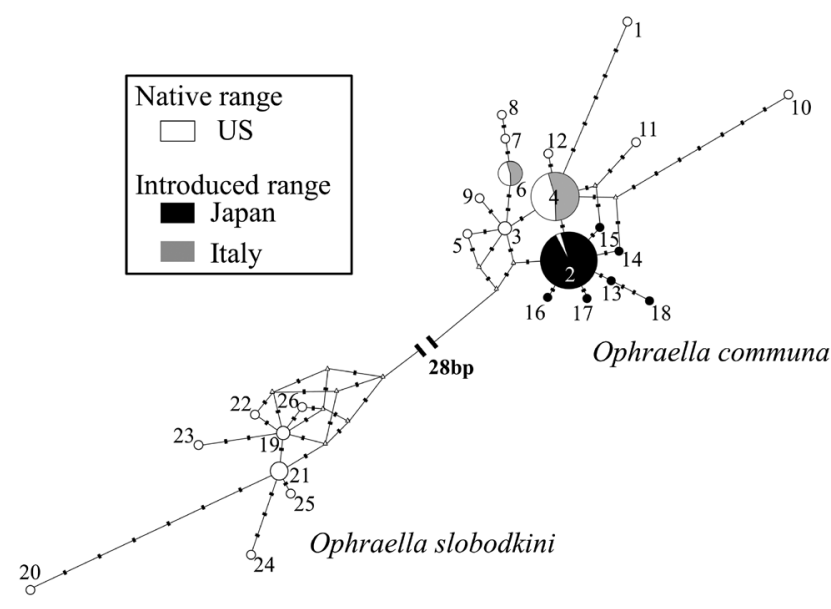

Fig. 2. Haplotype network for cytochrome c oxidase subunit (CO II) DNA sequences of Ophraella communa (right) and Ophraella slobodkini (left). The circle size is proportional to the number of individuals (1-33). Each line represents a single mutation. Empty triangles represent inferred non-sampled or extinct haplotypes.

\section{DNA Sequencing}

DNA was extracted from whole bodies of $O$. communa and O. slobodkini using a DNeasy blood \& tissue kit (Qiagen Inc., Hilden, Germany). The COII region of the extracted DNA was amplified using polymerase chain reaction (PCR) with primer
modified-A-tLeu (Simon et al., 1993; AATTTGGCAGATTATGCA) and C2-N-3661 (Simon et al., 1994; CCACAAATTTCTGAACATTGACCA). PCR was done using Takara Ex-Taq DNA polymerase (Takara Bio, Shiga, Japan) and a temperature profile of $95^{\circ} \mathrm{C}$ for $2 \mathrm{~min}$, followed by 30 cycles of $95^{\circ} \mathrm{C}$ for $30 \mathrm{~s}, 56^{\circ} \mathrm{C}$ for $30 \mathrm{~s}$ and $72^{\circ} \mathrm{C}$ for $2 \mathrm{~min}$. In a previous study, COI sequences were obtained for $O$. communa and $O$. slobodkini (Funk et al., 1995). To identify the two species, we sequenced COI from the specimens collected in southern areas of the United States within the area where the ranges of $O$. communa and O. slobodkini overlap. The PCR conditions (e.g., temperature profile and primers) used for COI were the same as those used by Funk et al. (1995). DNA sequencing was performed using an ABI 3130 DNA sequencer (Applied Biosystems, Foster City, CA). The resulting DNA sequences were deposited in GenBank with accession numbers KJ683911-KJ683936.

\section{Data analysis}

DNA sequences were edited visually and manually using MEGA 5.0 (Tamura et al., 2011). Multiple alignment of COII sequences was performed using ClustalW (Thompson et al., 1994) and MEGA default parameters. The 369 base pairs of partial sequences from the COII region were used for further analyses. To examine relationships among haplotypes of individuals of $O$. communa from the United States, Japan and Italy, we constructed a haplotype network (using Network 4.6.0; Fluxus Technology Ltd.), followed by median joining (Bandelt et al., 1999). The median joining algorithm estimates genetic networks from the minimum number of nucleotide differences. To estimate the genetic

TABLE 2. List of haplotypes and GenBank Accession numbers (KJ683911-KJ683936) for all haplotypes sampled in this study. A total of 18 haplotypes were recorded for Ophraella communa (Hap1-18) and 8 (Hap18-26) for O. slobodkini. Population names in bold type were collected from Ambrosia trifida and those in normal type collected from Ambrosia artemisiifolia. Numbers in parentheses are sample sizes.

\begin{tabular}{|c|c|c|c|}
\hline Haplotype no. & Sample size & Populations & Accession no \\
\hline 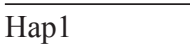 & 1 & US2(1) & KJ683911 \\
\hline Hap2 & 33 & $\begin{array}{c}\text { US1 (1), J1 (1), J2 (2), J5 (1), J6 (2), J7 (1), J8 (2), J9 (2), J10 (4), J11 (2), } \\
\text { J12 (2), J13 (6), J14 (5), J15 (2) }\end{array}$ & KJ683912 \\
\hline Hap3 & 2 & US8 (1), US4(1) & KJ683913 \\
\hline Hap4 & 23 & US2 (1), US3 (2), US7 (2), US8 (2), US9 (1), US10 (1), US16 (3), Italy1 (11) & KJ683914 \\
\hline Hap5 & 1 & US6 (1) & KJ683915 \\
\hline Hap6 & 5 & US5 (1), US8 (1), US12 (1), Italy1 (2) & KJ683916 \\
\hline Hap7 & 1 & US11 (1) & KJ683917 \\
\hline Hap8 & 1 & US11 (1) & KJ683918 \\
\hline Hap9 & 1 & US8 (1) & KJ683919 \\
\hline Hap10 & 1 & US7 (1) & KJ683920 \\
\hline Hap11 & 1 & US7 (1) & KJ683921 \\
\hline Hap12 & 1 & US8 (1) & KJ683922 \\
\hline Hap13 & 1 & $\mathrm{~J} 10(1)$ & KJ683923 \\
\hline Hap14 & 1 & J9 (1) & KJ683924 \\
\hline Hap15 & 1 & J4 (1) & KJ683925 \\
\hline Hap16 & 1 & $\mathrm{~J} 3(1)$ & KJ683926 \\
\hline Hap17 & 1 & J6 (1) & KJ683927 \\
\hline Hap18 & 1 & $\mathrm{~J} 5$ (1) & KJ683928 \\
\hline Hap19 & 2 & US13 (1), US18 (1) & KJ683929 \\
\hline Hap20 & 1 & US13 (1) & KJ683930 \\
\hline Hap21 & 4 & US14 (1), US15 (2), US18 (1) & KJ683931 \\
\hline Hap22 & 1 & US15 (1) & KJ683932 \\
\hline Hap23 & 1 & US17 (1) & KJ683933 \\
\hline Hap24 & 1 & US18 (1) & KJ683934 \\
\hline Hap25 & 1 & US18 (1) & KJ683935 \\
\hline Нар26 & 1 & US18 (1) & KJ683936 \\
\hline
\end{tabular}




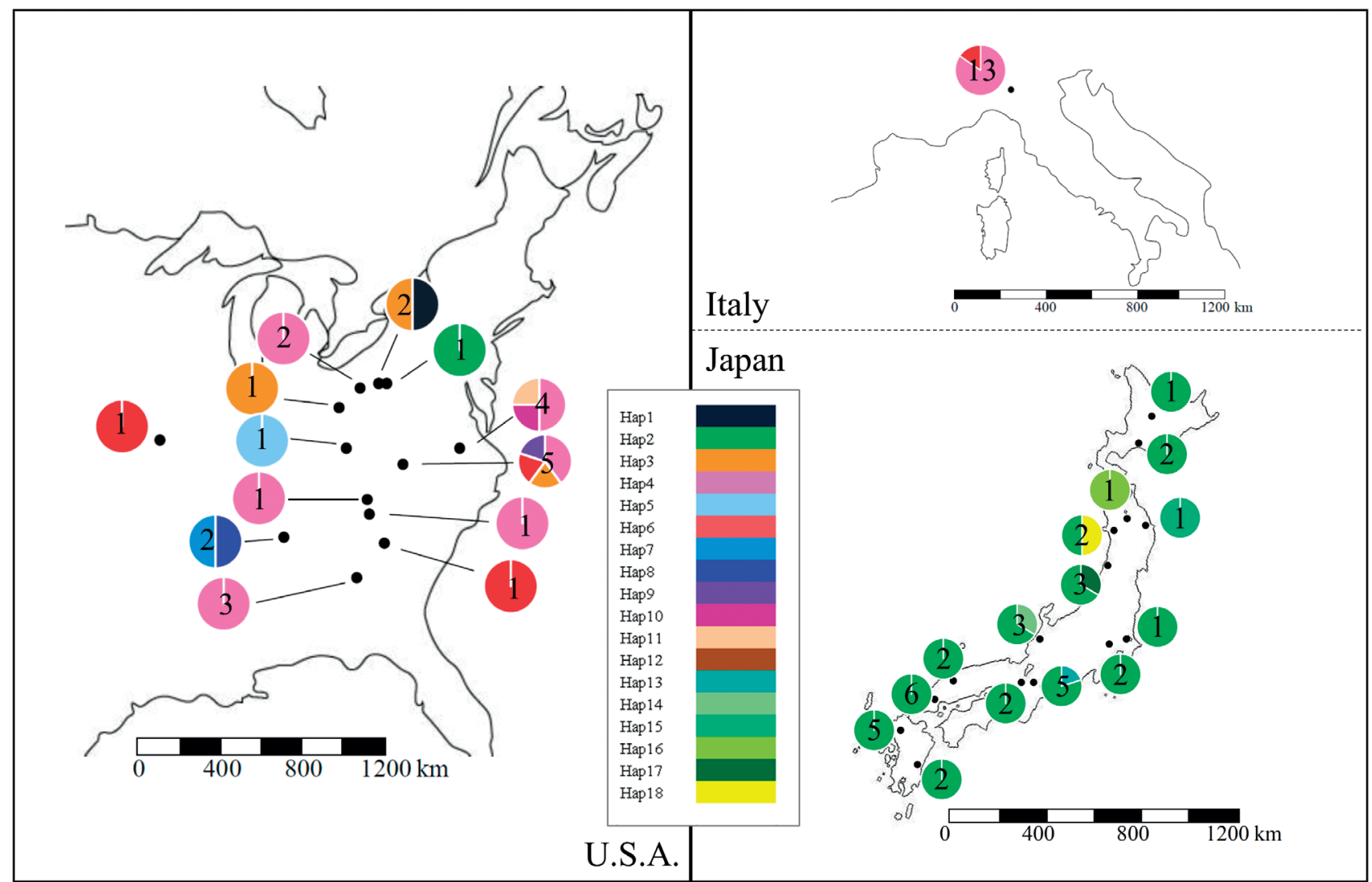

Native range

Introduced range

Fig. 3. The geographical distribution of haplotypes of Ophraella communa in USA, Japan and Italy. The numbers in the pie charts indicate the number of samples.

diversity of US, Japanese and Italian $O$. communa individuals, two standard diversity indices, haplotype diversity and nucleotide diversity (Nei, 1987), were calculated using Arlequin 3.5.1.2 (Excoffier \& Lischer, 2010). When estimating the genetic diversity in different countries, data from within each country were pooled. We sampled too few samples per population to examine population level differences. To determine the demographic history of the native and introduced populations of O. communa, we calculated Tajima's D, which determines departure from neutrality by measuring the disparity between the number of segregating sites and pairwise genetic distance (Tajima, 1989). Fu and Li's F* and D*, which are variations of Tajima's test (Fu \& Li, 1993), were calculated using the DnaSP program. These neutrality indices can be used to estimate past bottlenecks in population size or population expansions. We also estimated the nucleotide diversity in each country (average number of nucleotide differences per site within countries) and haplotype diversity (the likelihood that two individuals randomly chosen from a country have different haplotypes)

\section{RESULTS}

Based on the COII sequences, there were 26 haplotypes in the total sample of 89 individuals (Table 2). The haplotypes cluster into two distinct groups separated by at least 33 mutational steps (Fig. 2). Individuals from the two clusters were assigned respectively to $O$. communa and $O$. slobodkini based on COI sequences (Funk et al., 1995). Whereas 12 haplotypes of $O$. communa were found in the native populations, seven and two haplotypes were found, respectively, in the populations introduced into Japan and Italy (Table 1, Fig. 2). Eight haplotypes of O. slobodkini were found only in the southern populations in the native range, but not in the introduced populations (Fig. 1). No regional clustering of haplotypes was found among the native individuals. For example, haplotype 4 was found in widely separated native populations. Most of the Japanese individuals (84.2\%) have one haplotype (Hap. 2), which

TABLE 3. Genetic diversity and neutrality tests of native and introduced Ophraella communa.

\begin{tabular}{lcccccc}
\hline & $\mathrm{N}$ & $\mathrm{H}$ & $\pi$ & Tajima's D & Fu and Li's D* & Fu and Li's F* \\
\hline Total & 77 & $0.729 \pm 0.038$ & $0.00528 \pm 0.00088$ & $-2.141^{*}$ & $-3.950^{*}$ & $-3.904^{*}$ \\
Native range (US) & 25 & $0.785 \pm 0.081$ & $0.00802 \pm 0.00192$ & $-2.011^{*}$ & $-3.221^{*}$ & $-3.334^{*}$ \\
Introduced range (Japan) & 38 & $0.294 \pm 0.097$ & $0.00141 \pm 0.00061$ & $-2.095^{*}$ & $-2.717^{*}$ & $-2.955^{*}$ \\
Introduced range (Italy) & 13 & $0.282 \pm 0.142$ & $0.00230 \pm 0.00115$ & -0.394 & 1.086 & 0.803 \\
\hline
\end{tabular}

$\mathrm{N}$ - number of samples; $\mathrm{H}-$ haplotype diversity; $\pi$ - nucleotide diversity; $* p<0.05 ; * * p<0.01$. 
they share with an individual from the native population (Trafford, PA). The Japanese individuals showed a star-like pattern of six haplotypes arising from the most common haplotype (Fig. 2). Two haplotypes (Hap. 4 and Hap. 6) found in Italian individuals were also found in native individuals but not Japanese individuals (Fig. 2; Table 2).

Overall, there were lower levels of nucleotide and haplotype diversity in $O$. communa in its introduced ranges than in its native range (Table 3). Tajima's D, Fu and Li's D*, and $\mathrm{Fu}$ and Li's $\mathrm{F}^{*}$ statistics showed significant negative values for Japanese individuals and native individuals, but not for Italian individuals (Table 3).

\section{DISCUSSION}

In this study, we analyzed partial sequences of mitochondrial DNA to infer the invasion history of $O$. communa and compare the genetic diversity in native and introduced ranges. Although our dataset is preliminary and limited in terms of the numbers of individuals and populations sampled, our results suggest that introduced Japanese populations are less genetically diverse than the native North American population (Figs 2, 3; Table 3). Most Japanese individuals (33/38) shared one of the haplotypes found in the native range. As a result, the nucleotide and haplotype diversities of Japanese populations was much lower than that of populations in the United States (Table 2). In some of the Japanese populations there were none of the haplotypes recorded in the United States (Haplotype13-18) and these haplotypes differed by only a few nucleotides from the main haplotype in Japan (Haplotype 2). The unique haplotypes in Japan may result from sampling error because we collected only a few individuals per population. The low genetic variation recorded in the introduced populations indicate that the Japanese populations of $O$. communa resulted from a single major introduction rather than multiple introductions. For Japanese populations, we collected $O$. communa individuals feeding on both $A$. artemisiifolia and $A$. trifida. However, we recorded no genetic differentiation between these host-associated $O$. communa populations (Table 2). We also could not find a clear relationship between these haplotypes and the year in which the Ophraella beetles were collected.

Although our results suggest that the introduced Japanese populations were derived from a single major introduction, we were unable to identify the exact source populations of the introduced Japanese and Italian populations. This is because no regional clustering of haplotypes occurs among the native populations (Fig. 3). The absence of a regional clustering pattern in the native populations is consistent with the results of a previous study on O. communa based on mitochondrial COI sequences (Knowles et al., 1999). They suggest that this pattern reflects historical expansion associated with Pleistocene alternation of glacial and interglacial episodes. The significant negative values of the neutrality indices recorded for the native individuals (Table 3) are also consistent with the demographic history of past bottleneck events and/or recent population growth. Two haplotypes of Italian individuals were shared by na- tive individuals collected from several US populations. Although Italian individuals were collected from only one population, Italian haplotypes were not shared by Japanese individuals, suggesting that the introduction into Europe was independent of that into Japan. In the populations tested there was no evidence of a cryptic introduction of $O$. slobodkini into Japan and Italy. Futuyma (1991) reports a species boundary between $O$. communa and $O$. slobodkini along the Georgia-Florida border (Fig. 1). However, we found that the northernmost sampling site for O. slobodkini was near St. George, South Carolina in the native range (US13, US14 and US 15 in Fig. 1). During recent decades, data indicate that the boundary between $O$. communa and O. slobodkini might be shifting northwards.

ACKNOWLEDGEMENTS. We thank K. Tanaka for useful comments and helpful discussions. This work was supported by JSPS KAKENHI Grant Number 26-3225, the Fujiwara Natural History Foundation and The Japan Prize Foundation. Two anonymous reviewers greatly improved the manuscript.

\section{REFERENCES}

Allendorf F. \& LundQuist L. 2003: Introduction: population biology, evolution, and control of invasive species. - Conserv. Biol. 17: 24-30.

Bandelt H.J., Forster P. \& RöHl A. 1999: Median-joining networks for inferring intraspecific phylogenies. - Mol. Biol. Evol. 16: 37-48.

BASSETT I.J. \& CROMPTON C.W. 1975: The biology of canadian weeds: 11. Ambrosia artemisiifolia L. and A . psilostachya DC. - Can. J. Plant Sci. 55: 463-476.

Bassett I.J. \& CRompton C.W. 1982: The biology of canadian weeds: 55. Ambrosia trifida L. - Can. J. Plant Sci. 62: 10031010 .

Boriani M., Calvi M., Taddei A., Tantardini A., Cavagna B., Spadoni Andreani F., Montagna M., Bonini M., Lommen S. \& MÜLler-Schärer H. 2013: Ophraella communa segnalata in Italia su Ambrosia. - Inform. Agr. 69: 61.

Bosio G., Massobrio V., Chersi C., Scavarda G. \& Clark S. 2014: Spread of the ragweed leaf beetle, Ophraella communa LeSage, 1986 (Coleoptera Chrysomelidae), in Piedmont Region (northwestern Italy). - Boll. Soc. Entomol. Ital. 146: $17-30$.

BARRETT R.D. \& SChLUTER D. 2008: Adaptation from standing genetic variation. - Trends Ecol. Evol. 23: 38-44.

CAO Z., Wang H., Meng L. \& Li B. 2011: Risk to nontarget plants from Ophraella communa (Coleoptera: Chrysomelidae), a potential biological control agent of alien invasive weed $\mathrm{Am}$ brosia artemisiifolia (Asteraceae) in China. - Appl. Entomol. Zool. 46: 375-381.

Estoup A. \& Guillemaud T. 2010: Reconstructing routes of invasion using genetic data: why, how and so what? - Mol. Ecol. 19: 4113-4130.

ExCOFfIER L. \& Lischer H.E.L. 2010: Arlequin suite ver 3.5: a new series of programs to perform population genetics analyses under Linux and Windows. - Mol. Ecol. Res. 10: 564-567.

Fu Y.X. \& LI W.H. 1993: Statistical tests of neutrality of mutations. - Genetics 133: 693-709.

Fukano Y. \& Dor H. 2013: Population abundance and host use pattern of Ophraella communa (Coleoptera: Chrysomelidae) in its native and introduced range. - Biocontr. Sci. Tech. 23: 595-601. 
Funk D., Futuyma D., Orti G. \& Meyer A. 1995: A history of host associations and evolutionary diversification for Ophraella (Coleoptera: Chrysomelidae): new evidence from mitochondrial DNA. - Evolution 49: 1008-1017.

Futuyma D. 1991: A new species of Ophraella Wilcox (Coleoptera: Chrysomelidae) from the southeastern United States. N.Y. Entomol. Soc. 99: 643-653.

Guo J.-Y., Zhou Z.-S., Zheng X.-W., Chen H.-S., Wan F.-H. \& Luo Y.-H. 2011: Control efficiency of leaf beetle, Ophraella communa, on the invasive common ragweed, Ambrosia artemisiifolia, at different growing stages. - Biocontr. Sci. Tech. 21: 1049-1063.

Hufbauer R.A., Bogdanowicz S.M. \& Harrison R.G. 2004: The population genetics of a biological control introduction: mitochondrial DNA and microsatellie variation in native and introduced populations of Aphidus ervi, a parisitoid wasp. - Mol. Ecol. 13: 337-348.

Knowles L., Futuyma D., Eanes W. \& Rannala B. 1999: Insight into speciation from historical demography in the phytophagous beetle genus Ophraella. - Evolution 53: 1846-1856.

Kolbe J.J., Glor R.E., Rodríguez Schettino L., Lara A.C., LarSON A. \& Losos J.B. 2004: Genetic variation increases during biological invasion by a Cuban lizard. - Nature 431: 177-181.

LAVERGNe S. \& MolofsKy J. 2007: Increased genetic variation and evolutionary potential drive the success of an invasive grass. - Proc. Natl. Acad. Sci. USA 104: 3883-3888.

Müller-Schärer H., Lommen S.T.E., Rossinelli M., BoninI M., Boriani M., Bosio G. \& Schaffner U. 2014: Ophraella communa, the ragweed leaf beetle, has successfully landed in Europe: fortunate coincidence or threat? - Weed Res. 54: $109-119$.

NeI M. 1987: Molecular Evolutionary Genetics. Columbia University Press, New York, $\mathrm{x}+512 \mathrm{pp}$.

Sakai A.K., Allendorf F.W., Holt J.S., Lodge D.M., Molofsky J., With K.A., Baughman S., Cabin R.J., Cohen J.E., Ellstrand N.C., McCauley D.E., O’Neil P., Parker I.M., Thompson J.N.
\& WeLLER S.G. 2001: The population biology of invasive species. - Annu. Rev. Ecol. Syst. 32: 305-332.

Sax D., Stachowicz J. \& Gaines S. 2005: Species Invasion: Insights into Ecology, Evolution and Biogegraphy. Sinauer Associates, Sunderland, MA, $480 \mathrm{pp}$.

SHIYAKE S. \& MorIYA S. 2005: Expansion of Ophraella communa Lesage in East Asia. - Kontyu to Shizen 40: 11-13 [in Japanese].

Simon C., Mcintosh C. \& Deniega J. 1993: Standard restriction fragment length analysis of the mitochondrial genome is not sensitive enough for phylogenetic analysis or identification of 17-year periodical cicada broods (Hemiptera: Cicadidae): The potential for a new technique. - Ann. Entomol. Soc. Am. 86: 228-238.

Simon C., Frati F., Beckenbach A., Crespi B., Liu H. \& Flook P. 1994: Evolution, weighting, and phylogenetic utility of mitochondrial gene sequences and a compilation of conserved polymerase chain reaction primers. - Ann. Entomol. Soc. Am. 87: 621-701.

TалIMA F. 1989: Statistical method for testing the neutral mutation hypothesis by DNA polymorphism. - Genetics 123: 585-595.

Tamura K., Peterson D., Peterson N., Stecher G., Nei M. \& KUMAR S. 2011: MEGA5: molecular evolutionary genetics analysis using maximum likelihood, evolutionary distance, and maximum parsimony methods. - Mol. Biol. Evol. 28: 2731-2739.

Thompson J.D., Higgins D.G. \& Gibson T.J. 1994: CLUSTAL $\mathrm{W}$ : improving the sensitivity of progressive multiple sequence alignment through sequence weighting, position-specific gap penalties and weight matrix choice. - Nucl. Acids Res. 22: 4673-4680.

Zhou Z.-S., Chen H.-S., Zheng X.-W., Guo J.-Y., Guo W., Li M., Luo M. \& Wan F.-H. 2014: Control of the invasive weed Ambrosia artemisiifolia with Ophraella communa and Epiblema strenuana. — Biocontr. Sci. Tech. 24: 950-964.

Received December 19, 2014; revised and accepted June 26, 2015 Prepublished online August 27, 2015 